\title{
Ungdommens røst: om forebygging av psykiske vansker og villet egenskade
}

Ved Guro Wattum Sandlie og Mette Ystgaard

\begin{abstract}
I løpet av 2000 og 2001 ble multisenterstudien 'Villet egenskade blant ungdom i Europa', den såkalte CASE-studien, gjennomført i syv land med Norge som ett av deltakerlandene. På slutten av spørreskjemaet som ble benyttet i studien, ble ungdommene bedt om å skrive med egne ord hva de mente kunne bidra til å forebygge psykiske vansker og selvskadende atferd. Svarene på disse åpne spørsmålene i den norske delstudien ga viktige innspill om både formelle og uformelle nettverk som skole, venner og familie. Ungdommene hadde gode idéer og mange klare svar om forebyggende tiltak. Dette vil vi presentere i denne artikkelen, som er en bearbeiding av en prosjektoppgave ved Videreutdanning $i$ selvmordsforebyggende arbeid, Universitetet i Oslo (Sandlie \& Husby, 2003).
\end{abstract}

\section{Bakgrunn}

Studier viser at til enhver tid har omtrent $20 \%$ av tenåringer psykiske vansker, hvorav mellom 5 og $8 \%$ har alvorlige psykiske lidelser ( $\mathrm{N}$ asjonalt kunnskapssenter, 2004; C ostello et al., 2005). O ver $10 \%$ har en eller annen gang påført kroppen sin skade med vilje (Y stgaard et al., 2003). Enkelte problemer, som depresjon og villet egenskade, ser ut til å øke i omfang (Rossow, 2005; Kvalem \& W ichstrøm, 2007). Enten det gjelder villet egenskade eller psykiske vansker, får langt fra alle som har behov, profesjonell hjelp (H eiervang et al., 2007; Y stgaard, 2003). På denne bakgrunn er det naturlig at forebyggende tiltak har vært viet stor oppmerksomhet både i faglitteraturen og $\mathrm{i}$ praksisfeltet. Det er imidlertid påfallende hvor lite ungdommer selv er blitt spurt om forebygging og hva de mener kan hjelpe når de har problemer. Dette fikk vi mulighet til å undersøke da N orge var med i en større multisenterstudie Villet egenskade blant ungdom i Europa, den såkalte CA SE-studien som ble gjennomført i syv land (Ystgaard et al., 2003).

\section{Metode}

Den norske delen av CA SE-studien ble gjennomført blant alle grunnkurselever i H edmark og 0 ppland i 2000 og 2001. U ndersøkelsen hadde som hovedhensikt å få mer kunnskap om omfanget av villet egenskade, hva som kjennetegner selvskaden de unge og i hvilken grad, og eventuelt hvor, de făr hjelp. Det omfattende spørreskjemaet, som ble besvart $i$ en skoletime, engasjerte og svarprosenten ble høy ( $92 \%)$. I alt fikk vi svar fra 4060 elever, 2090 gutter og 1970 jenter. M ajoriteten var mellom 15 og 16 år. $M$ ange var åpenhjertige og formidl et mye lidelse og ulykkelighet, men også håp og optimisme. På slutten av spørreskjemaet ble ungdommene oppfordret til å svare på følgende åpne spørsmål om forebygging:

- H va mener du kan gjøres for å hindre at unge mennesker skader seg selv ( tar overdose, eller skader seg selv på annen måte, som ved å kutte eller skjære seg)?

- H va kan gjøres på skolen og $\mathrm{i}$ nabolaget ditt for å gjøre livet bedre for unge mennesker?

I tillegg ble de spurt om erfaringer med hjel peapparatet:

- $\mathrm{H}$ ar du selv hatt positive eller negative erfaringer med hjel peapparatet? Kan du kort beskrive hva du har opplevd?

\section{Kvalitative og kvantitative analyser}

Svarene ungdommene ga, er gjort til gjenstand for både kvantitative og kvalitative analyser. De kvalitative analysene foregikk $i$ to trinn. Først gjennomførte vi en innholdsanalyse av samtlige svar på de åpne spørsmålene. G jennom denne analysen fikk vi grovsortert svarene $i$ temaområder eller kategorier.

Deretter gjorde vi en ny innholdsanalyse av hver kategori for å finne ut hvilke tema som igjen utkrystalliserte seg innen kategoriene (Kvale, 2004). For å undersøke reliabiliteten av de identifiserte kategoriene, ble det gjennomført en interrater-reliabilitetstest. Kappaverdiene var i hovedsak høye.

I tillegg til å være utgangspunkt for kvalitative fordypningsanalyser, ble kategoriene også benyttet for enkle kvantitative beregninger: $\mathrm{H}$ vor man ge svarte innen hver kategori? Var det kjønns- eller fylkesvise forskjeller i omfang av svar? O g ikke minst, var det forskjell i omfang av svar fra de som selv hadde rapportert villet egenskade og de som ikke hadde rapportert slik atferd?

\section{Resultater}

A $v$ de 4060 ungdommene som besvarte hovedskjemaet, var det 2273 som besvarte de åpne spørsmålene på slutten av skjemaet.

Vi vil først se hvordan svarene på de åpne spørsmålene fordelte seg.

Det var en større andel jenter enn gutter ( $60,2 \%$ vs. $52,5 \%$ - chi-kvadrat $\mathrm{p}<0.001)$ og flere fra 0 ppland enn H edmark ( $64,8 \%$ vs. $47,6 \%$ - chikvadrat $p<0.001$ ) som besvarte de åpne spørsmålene. $M$ en det var ingen signifikant forskjell i svarfrekvens mellom de som rapporterte episoder med villet egenskade og de som ikke hadde rapportert slike episoder.

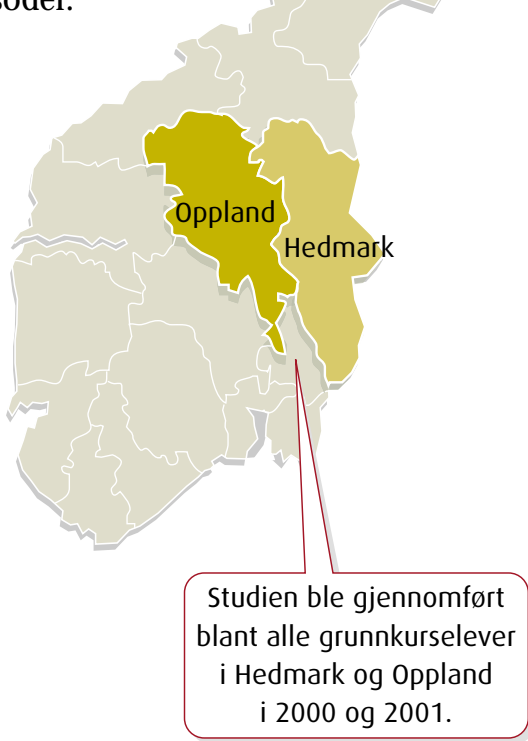




\section{Kategoriene}

Første trinn i den kvalitative analysen resulterte i føl gende kategorier:

O msorg: 0 mhandler svar om å bry seg og vise oppmerksomhet.

- H jelpeapparatet: Inkluderer svar som omhandlet holdninger og forhold til hjelpeapparatet.

- Vennerelasjoner: O mhandler de svarene som eksplisitt har med de unges egen rolle $\mathrm{i}$ forhold til andre jevnaldrende å gjøre.

- M obbing: Inkluderer alle svar som inneholder momenter av denne problematikken.

- F ritid: I dette ligger det alle former for fritidsaktiviteter som ungdommen etterlyser.

- Rus: Her inkluderes alle temaer som omhandler rus.

- Skole: Innenfor denne kategorien har vi tatt med de utsagnene som omhandler lærerrollen og det ungdommen mener er viktig å gjøre på skolearenaen for å forebygge.

Tabell 1 viser hvor mange av svarene på de åpne spørsmålene som ble inkludert i hver kategori.

Tabell 1. Spørreundersøkelse om villet egenskade blant elever i videregående skole i Hedmark og 0ppland 2000/01. Andel av svarene ( $n=2273)$ på de åpne spørsmålene som ble inkludert i hver kategori, samlet og etter kjønn.

\begin{tabular}{|c|c|c|c|c|}
\hline & $\begin{array}{l}\text { Totalt besvart } \\
(n=2273)\end{array}$ & $\begin{array}{c}\text { Gutter } \\
(n=1093)\end{array}$ & $\begin{array}{c}\text { Jenter } \\
(n=1180)\end{array}$ & Chi-kvadrat \\
\hline Kategorier & $(n)$ & $\%$ & $\%$ & \\
\hline Omsorg & (1023) & 34,4 & 54,8 & $95,68^{\star * *}$ \\
\hline Hjelpeapparatet & (315) & 11,2 & 16,4 & $12,82^{\star \star \star}$ \\
\hline Vennerelasjoner & (269) & 7,5 & 15,8 & $37,87^{\star \star \star}$ \\
\hline Mobbing & (88) & 2,5 & 5,2 & $11,10^{\star \star}$ \\
\hline Fritidsaktiviteter & $(727)$ & 31,6 & 32,4 & 0,17 n.s. \\
\hline Rus & $(72)$ & 4,2 & 2,2 & $7,46^{\star \star}$ \\
\hline Skolen & $(285)$ & 9,7 & 15,2 & $15,42^{\star \star \star}$ \\
\hline Vet ikke & (205) & 12,7 & 5,7 & $34,27^{\star \star \star}$ \\
\hline Tull & (63) & 5,3 & 0,4 & $50,30^{\star \star \star}$ \\
\hline Annet & (472) & 22,6 & 19,1 & $4,38^{\star}$ \\
\hline
\end{tabular}

Eksempler som illustrerer svarene under denne kategorien er:

"V ise de at noen bryr seg om dem. Snakke med dem, gi dem oppmerksomhet og få de til å forstå at noen bryr seg."

"V ed at foreldre tar seg tid til å lytte/snakke med dem og være oppmerksomme" .

"A t foreldre er litt mer oppmerksomme om det kan være vanskelig. $M$ en at de prøver å bygge opp et sterkt forhold til barna sine når barna er små. A t de prøver å være forståelsesfulle med barna sine når de tror at barna deres har det vanskelig".

"F oreldre og andre voksne kan være litt mer imøtekommende. J eg har en følelse av at ungdomsproblemer ofte blir avfeid som ting som sikkert går over etter en liten stund".

A v de 315 svarene om $\mathrm{H}$ jel peapparatet pekte det seg ut to tema, tilgjengelighet og fortrolighet. Eksempler på hva ungdommene gir av svar er:

"A t det blir lettere å søke hjelp. A t hjelpeapparatet blir mer tilgjengelig. Jeg tror det er lettere å søke hjelp i store byer der man ikke kjenner de som jobber der. D et er vanskelig å åpne seg når man ser personen på gata hver dag".

" M er hjelp fra profesjonelle. U ngdom vet ikke hvor de skal henven de seg. D et er viktig med informasjon om hvem du kan ta kontakt med osv."

"H jelpeapparatet er der men det er ingen som bruker det, de tør rett og slett ikke fordi dem stoler ikke på dem... . D e burde ha samtaler med elever mye oftere".

"Jeg mener at de som trenger hjelp burde få den hjelpen de trenger. Jeg var en som selv trengte hjelp. U ngdomsgrupper var noe som kom meg til nytte".

U nder kategorien Vennerelasjoner kom temaene kvaliteten på vennskap og venner som formidlere tydelig fram av de 269 svarene. Eksempler på sitater under denne kategorien er:

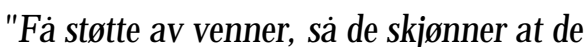
virkelig betyr noe." 
"A t venner virkelig stiller opp. I kke plutselig begynner å lyve, gjøre ting som kan få deg til å føle at du ikke er god nok."

"H va unge mennesker trenger mest av alt er en venn, ung eller kanskje voksen, i alle fall en de kan stole $100 \%$ på, som tror på dem, trøster dem. U ngdom trenger også å vise kjærlighet, trøste noen, med andre ord "gi og ta" til/fra en venn. $\mathrm{H}$ a noen å dele ting med".

"[... ] Jeg tror det er vennene som kan få en person til å endre mening."

A v de 285 som hadde synspunkter på hva skolen kunne gjøre, var det to temaer som skilte seg ut: bygge godt læringsmiljø og stoff om psykisk helse i fagplanene.

Her kan vi nevne eksempler som:

"Ingen må bli oversett. H vis læreren ser at en elev står alene i skolegården, må læreren ta tak i problemet. D et er nemlig ikke så ofte at elevene selv legger merke til det."

"D ersom skolen hadde flettet inn psykologi i lærerplanen, ville ungdom lære mer om sitt eget sinn, og kanskje bli bedre rustet til å takle kriser og andre vanskeligheter."

"Skolen må bare passe seg for å være det lille ekstra som velter skålen, skolen må snakke med elevene som har problemer på skolen, og prøveå hjelpe dem på rett kurs. $H$ vis noen ting ordner seg, er det lettere at andre ting gjør det også?!"

"Bli kvitt det dårlige miljøet det er på mange norske skoler. Lære ungdom hvordan vi skal behandle hverandre. B li kvitt problemer med en gang de kommer. I kke la det utarte seg. Den viktigste tingen er at alle må ha en venn".

\section{Erfaringer med hjelpeapparatet}

$1168(51,4 \%)$ svarte på det tredje åpne spørsmålet om erfaring med hjel peapparatet. A v disse svarte 56,4 \% $(n=659)$ at de ikke har noen erfaring med hjelpeapparatet. Blant dem som hadde hatt erfaringer med hjel peapparatet, svarer $14 \%(n=164)$ at de hadde egne positive erfaringer, mens $9,4 \%(n=110)$ sa de hadde egne negative erfaringer. 1,8 \% $(n=21)$ ga uttrykk for at begrepet hjelpeapparat var ukjent for dem.

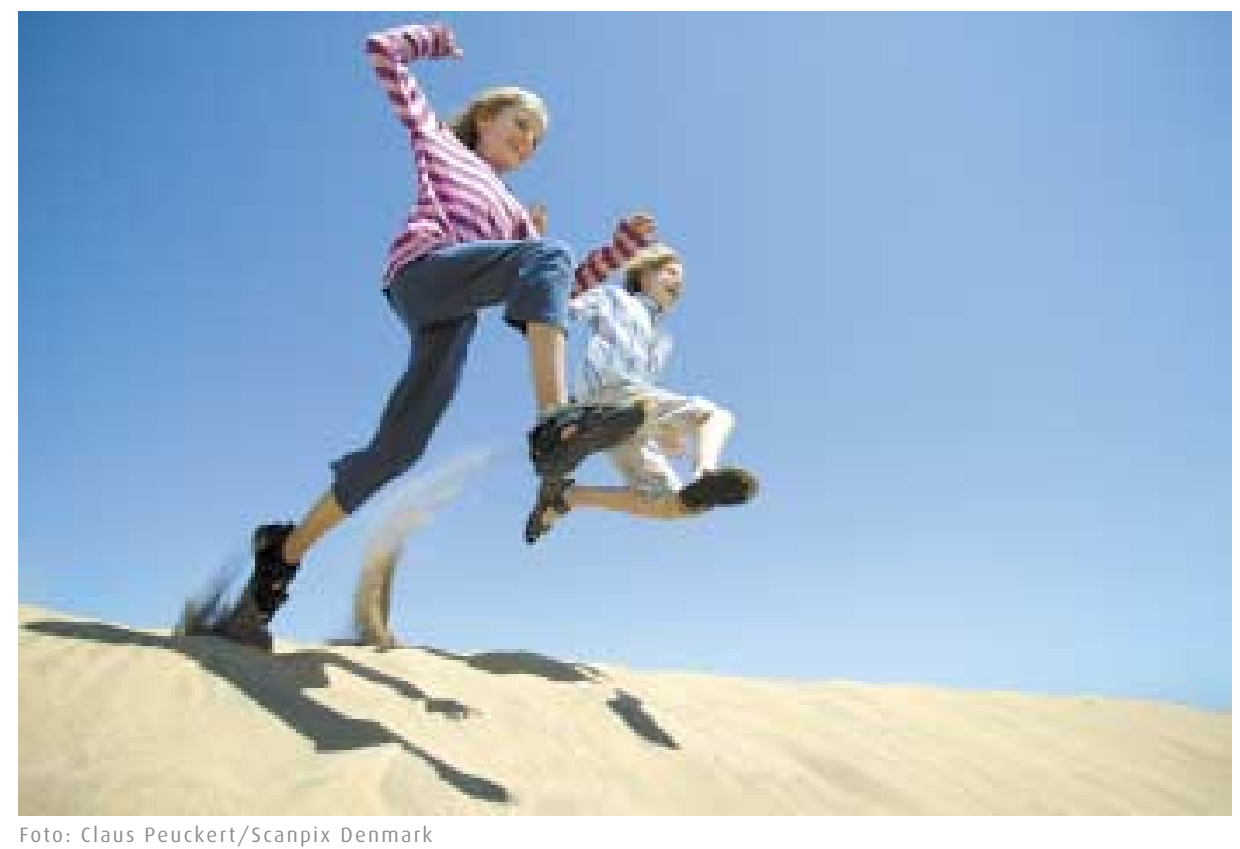

Hva kan vi lære av ungdommenes svar?

Vi vil i det føl gende diskutere tre forhold som i særlig grad pekte seg ut gjennom våre analyser av hva ungdommene formidlet; nemlig forhold til hjelpeapparatet, omsorg og støtte og skolen som arena for forebygging.

\section{Ungdoms forhold til hjelpeapparatet}

Både resultater fra C A SE-studien og andre større epidemiologiske studier viser at ungdom som har alvorlige problemer, i liten grad har kontakt med det profesjonelle hjel peapparatet ( $\mathrm{H}$ eiervang et al, 2007; Y stgaard, 2003). Spørsmålet blir da hvorfor de ikke søker hjelp, til tross for at de har behov for det. Forklaringene er mange og sammensatte. $\mathrm{N}$ oen forklaringer ligger kanskje i ungdommenes svar.

\section{Informasjon}

$M$ ange gir uttrykk for at hjelpere ikke er flinke nok til å markedsføre seg, de unge vet ikke hvor de kan få hjelp hvis de trenger det, og heller ikke hvilken hjelp som tilbys ved ulike instanser. En liten del av de som ikke hadde noen erfaring med hjelpeapparatet, uttrykte at de ikke visste hva det var eller hva det betydde. Dette kan tyde på at voksne bruker begreper uten å reflektere over om dette er begreper som ungdom forstår. $\AA$ markedsføre hjel peinstansene tydeligere, ikke minst når det gjelder innhold, vil kunne øke ungdoms mulighet og interesse for å ta kontakt.

\section{Erfaringer og holdninger}

Det er viktig å merke seg at av de som har hatt kontakt med hjelpeapparatet, er flere positive enn negative. $M$ ange opplever god hjelp. U t fra de som beskriver negative opplevelser, er det først og fremst opplevelsen av ikkeå bli møtt som er fremtredende. Tillit til helsetjen esten er helt vesentlig for at ungdommen skal oppsøke den. Respekten for den enkeltes autonomi og integritet er kjerneverdier for den norske hel setjenesten. Spørsmålet om hvordan dette uttrykkesi ord og handlinger $\mathrm{i}$ arbeidet med ungdom, er helt grunnleggende. Vise respekt og å bli tatt på alvor er svært viktige budskap ungdommene gir til oss.

Ungdommenes holdninger til hjelpeapparatet vil også være basert på venners og familiemedl emmers erfaringer og holdninger. Terskelen for å bruke helsetjenesten vil være influert av hvordan andre ungdommer tenker og bruker dette tilbudet. Både svar i denne undersøkelsen og resultater fra tidligere undersøkelser viser at mange unge er forbeholdne når det gjelder å søke hjelp for psykiske vansker. Det er flaut å ha psykiske problemer, skriver flere. I en tidligere spørreundersøkelse i videregåen de skole ble ungdom spurt hva de ville gjøre dersom de ble betrodd al vorlige selvmordstanker av en venn. 
De færreste ville råde vennen sin til å ta kontakt med psykolog eller psykiater (Ystgaard, 1993). Redsel for utstøting og for å komme i et dårlig lys blant vennene kan overskygge det å søke den hjelpen man har behov for. Svarene viser at det er et stort behov for kunnskap og holdningsbearbeiding rettet både mot ungdommene selv og befolkningen for $ø v$ rig. Det er derfor gledelig at Sosial- og helsedirektoratet denne høsten har en stor kampanje om ungdom og psykisk helse. Kampanjen inkluderer undervisningsopplegg til lærere, informasjon til elever og foreldre, annonser, film og kinoreklame. H ensikten er å gi ungdom og andre informasjon om psykiske helse og å forebygge psykiske problemer.

\section{Tilgjengelighet}

Et annet tydelig signal er ønsket om et tilgjengelig hjel peapparat. $M$ ange mener at det tar for lang tid å få hjelp. $0 \mathrm{~g}$ de påpeker behovet for at hjelpen må være der når de føler de trenger den. De ønsker en tilgjengelig helsetjeneste på skolen . $M$ ange etterlyser også mer fleksible tilbud med mulighet for lavterskeltilbud, også ut over vanlig kontortid. Disse ønskene er i tråd med nyere modeller for organisering av hjel petjenester for barn og unge. $M$ ange kommuner har nå utviklet lavterskeltilbud, som for eksempel i familiesentre, samordnet tilbud fra skolehelsetjen esten og BU P med samlokalisering på skolen, og i helsestasjon for ungdom som ofte er betjent med både psykolog og helsesøster. Generelt er det mange nye initiativ for å få et mer fleksibelt samarbeid og mer hensiktmessig arbeidsfordeling mellom første- og andrelinjetjenesten.

Flere av kommentarene fra ungdom viser at de mangler informasjon om hvordan hel setjenesten i dag fungerer. Blant annet sier flere at de ikke søker hjelp fordi det å søke hjelp hos lege, psykolog og psykiatrisk poliklinikk koster penger. For noen blir det da et problem å gå til foreldre og be om penger dersom de sliter med forhold i livet som de ikke ønsker å snakke med foreldrene om. En lignende misforståelse som ofte refereres, er at ventelistene er så lange at det ikke er noen vits i å prøve å søke hjel p. Informasjon om at tjenestene er gratis og at de fleste kan få hjelp raskt dersom det er behov for det, er derfor viktig informasjon til de unge.

\section{Omsorg og sosial støtte}

Forhold til voksne

$\mathrm{N}$ ærmere halvparten av dem som har svart på de åpne spørsmålene, har tatt opp forhold som har med omsorg å gjøre. D e er opptatt av betydningen av å bry seg, og de opplever at denne rollen er det viktig at de voksne har og tar. N år ungdom sier at voksne må bry seg mer, gi oppmerksomhet og støtte, etterlyser de det forskningen lenge har påpekt.

O pplevelse av samhold og sosial støtte beskytter mot psykisk problemer, særlig i perioder når man har store livsbelastninger (C ohen \& Wills, 1985; Ystgaard et al., 1999).

$\mathrm{N}$ år de unge etterlyser at de voksne virkelig tør å bry seg og snakke med ungdommene og ikke bare om dem, byr dette på utfordringer ikke bare for foreldregruppen, men også blant fagmiljøene, politikere og voksne generelt. For det de unge formidler, er at vi må låne øre til hva de faktisk forteller oss når de har det vanskelig, ikke hva vi tror de forteller oss ut fra vår egen referanseramme.

Faglitteraturen viser at ungdom først og fremst søker venner som fortrolige når de har problemer. Det er derfor tankevekkende at så mange etterlyser mer engasjement og initiativ fra voksne. Er det da slik, som M ehlum (2003) er inne på i sin

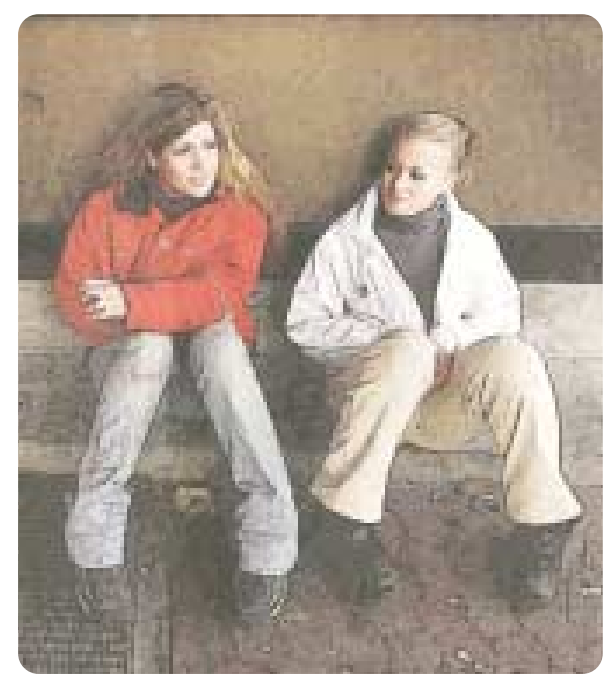

redaktørartikkel i Suicidologi, at de unge ønsker å skjerme foreldrene og nære voksne fra å vite at de sliter fordi de er glad i dem og ikke ønsker å påføre dem belastninger? Eller er den distansen mange unge beskriver mellom de voksnes og de unges verden så stor at det føles unaturlig for dem å henvende seg til de voksne? Eller lar unge være å ta kontakt med voksne ut fra erfaringer om at samhandling med voksne ikke er så jevnbyrdig og likeverdig som de ønsker? $\AA$ formidle kunnskap til voksne om ungdomskulturen, psykiske lidelser og villet egenskade blant ungdom vil her kunne være et nyttig forebyggende tiltak.

Vennerelasjonen

$0 \mathrm{~m}$ ungdom etterlyser mer kontakt med voksne, betyr ikke det at venner er mindre betydningsfulle. Venner er det viktigste vi har, formidles gjennom mange av svarene. De gir vennskap en kvalitativ betydning utover det å være sammen.

Den støtten de og involverende funksjonen blir sterkere enn tidligere i livet. I mange sammenhenger får ikke foreldrene eller andre nære voksne kjennskap til problemene den unge har, fordi vennemoralen kan kreve både taushet og lojalitet. De voksne blir da ute av stand til å hjel pe, og jevnaldrende venner som kjenner problemet, får for stort ansvar og har i mange tilfeller ikke den nødvendige erfaringen for å vite hva de kan gjøre for å hjelpe.

Betydningen av trygge unge og voksne hjel pere uttrykker Svein Ø verland (2006) slik:

"... . O fte gjør bekymrede venner og foreldre situasjonen verre for en som skader seg - bekymringen og usikkerheten kan forsterke den dårlige samvittigheten og skamfølelsen hos selvskaderen. På den annen side kan støtte og trygghet hos venner og foreldre i seg selv bidra til at ungdommen blir mer motivert til å slutte å skade seg, og det kan øke både behandlingsmotivasjonen og effekten av behandling." ( $\varnothing$ verland, 2006, s. 237) 


\section{Skolens og lærernes betydning}

$M$ ange la vekt på det relasjonelle $\mathrm{i}$ forholdet til læreren, og mente at det er viktig at også lærerne bryr seg når de ser at noen har problemer, og at de behandler dem med respekt. U ndersøkelser viser at Iærerne har en mer sentral rolle for elevene enn det lærerne selv tror (Ystgaard, 1993). U ngdommene i vår undersøkelse bekrefter dette.

$M$ ange framhever også at press for å lykkes både sosialt og faglig kan gi psykiske plager. R esultater i delrapporten "M estring, hjelp og støtte" (Ystgaard et al., 2001) viser at ungdommer på grunnkurs i mye større grad får fagl ige problemer enn de har opplevd i tidligere skolegang. Vi bør derfor ha et ekstra blikk for problemer ungdom kan få i overgangen til videregående skole.

Flere trekker frem betydningen av et godt skole- og klassemiljø. Det å jobbe systematisk for å skape et godt klassemiljø kan redusere fraværet, og øke trivselen og tryggheten både blant lærere og elever. I utviklingen av et godt klassemiljø er lærerens bidrag av stor betydning. Dessuten er det viktig å skape en felles forståelse og en grunnholdning i skolen som organisasjon for hva det innebærer å ha et godt læringsmiljø, og hva den enkelte må bidra med for å skape dette. Rutter (1979) bruker i den sammenheng begrepet skolens ethos. Det vil si skolens atmosfære og grunnholdning som organisasjon.

Det var også mange som etterlyste kunnskap om psykisk helse i fagplanene. Det er derfor gledelig at Sosial- og helsedirektoratet nå har en egen satsing: Psykisk helse i skolen. Forhåpentligvis vil mange av de programmene som brukes i denne satsingen, kunne imøtekomme noen av elevenes ønsker.

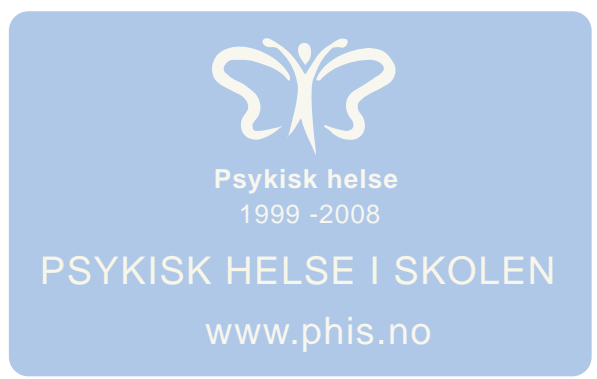

\section{Oppsummerende kommentar}

Innenfor rammen av en prosjektoppgave er det begrensninger i hvor dypt og omfattende det har vært mulig å behandle det aktuelle datamaterialet. Likevel har vi fått nyttig informasjon om hvordan ungdom selv tenker om forebygging og om hjel peapparatet. Det er interessant at deres ønsker om hjelpeapparatet på mange måter samsvarer med hvordan tjenestene i dag søkes utformet, med større til gjengelighet og mer tverrfaglig samarbeid og tverretatlig samordning. A t også de unge peker på viktigheten av grunnleggende verdier som omsorg, tillit og respekt bekrefter vårt felles fundament som hjelper og hjelpsøker. På noen områder ligger det imidlertid en spenning eller utfordring $\mathrm{i}$ budskapet fra de unge. For det første har de et klart budskap til voksenverdenen om at vi må bry oss mer! Videre er det en utfordring at mange unge ikke søker den hjelpen de har behov for og rett til. $M$ ange vet lite om hvor hjelpen finnes, og de har mangelfull kunnskap om ulike muligheter og rammer for hjel petilbudene. H er utfordres vi på å påvirke negative holdninger til selvskadende atferd og psykiske problemer, og på å nå fram med faktisk informasjon om ulike psykiske problemer og muligheter for hjelp.

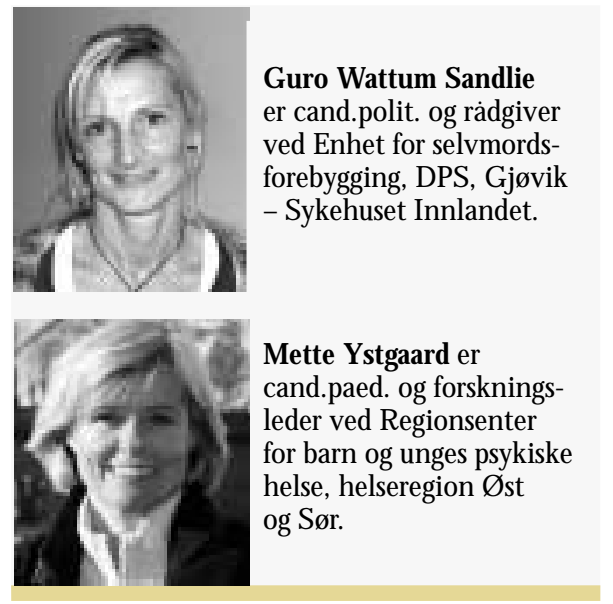

\section{Referanser}

Cohen, S., \& W ills, T.A . (1985). Stress, social support and the buggering hypotheses. Psychol Bull, 98, 310- 357
Costello, E.J., Egger, H., \& A ngold, A . (2005). 10-year research update review: the epidemiology of child and adolescent psychiatric disorders: I. M ethods and public health burden. I A $m$ A cad C hild A dolesc Psychiatry, 44(10), 972-86.

G rønmo,S.(2004). Samfunnsvitenskapelige metoder. Bergen: Fagbokforlaget.

H eiervang, E., Stormark, K. M ., Lundervold, A . J., H eimann, M ., Goodman, R., Posserud, M . B., U Ilebo, A . K., Plessen, K. J., Bjelland, I., Lie, S. A ., \& Gillberg, C. (2007). Psychiatric disorders in $\mathrm{N}$ orwegian 8- to 10-year-olds: an epidemiological survey of prevalence, risk factors, and service use. J A m A cad C hild A dolesc Psychiatry, 46(4), 438-47.

\section{Kvale, S. (2004). D et kvalitative}

forskningsintervju. 0 slo: $\mathrm{G}$ ylden dal.

K valem, I. L., \& W ichstrøm, L. (red.). (2007). U ng i N orge. Psykososiale utfordringer. 0 slo: C appel en akademisk.

M ehlum, L.(2003). R edaktøren har ordet. Suicidologi, 2, 2.

$\mathrm{N}$ asjonalt kunnskapssenter. (2004). H elseprofil barn og unge.

Rossow, I., G roholt, B., \& W ichstrom, L.(2003). Intoxicants and suicidal behaviour among adolescents: changes in levels and associations from 1992 to 2002. A ddiction, 100, 79-88.

Rutter, M ., M aughan, B., \& M otimore, P. (1979). Fifteen thousand hours. Bath: The Pitman Press.

Sandlie, G.W., \& H usby, J. (2003): U ngdommens røst. Prosjek toppgave - Videreutdanning for selvmordsforebyggende arbeid. 0 slo: U niversitetet i 0 slo, Seksjon for selvmordsforskning og -forebygging.

Y stgaard, M., Reinholdt, N .P., H usby, J., \& M ehlum, L.(2003). Villet egenskade blant ungdom. Tidsskrift for $D$ en norske lægeforening, $123,16,2241-5$.

Ystgaard, M . (2003). Villet egenskade blant ungdom: nye forskningsresultater og konsekvenser for forebyggende arbeid. Suicidologi, 8, 7-10.

Ystgaard, M., Reinholdt, N . P., \& M ehlum, L. (2001). M estring, hjelp og støtte: resultater fra videregående skole i 0 ppland: delrapport fra forskningsprosjektet $\mathrm{C}$ hild and adolescent selfharm in Europe (CA SE). 0 slo: U niversitetet $i$

O slo, Seksjon for selvmordsforskning og -forebygging.

Ystgaard, M ., Tambs, K., \& Dalgard, O. S. (1999). Life stress, social support and psychological distress in late adolescence: a longitudinal study. Social Psychiatry and Psychiatric Epidemiology, 34, 12-19.

Y stgaard, M .(1993). Sårbar ungdom og sosial støtte - en tilnærming til forebygging av psykisk stress og selvmord. 0 slo: Senter for sosialt nettverk og helse. Rapport nr.1/1993.

$\emptyset$ verland, S. (2006). Selvskading: en praktisk tilnærming. Bergen: Fagbokforlaget. 